\section{A Simplified Method for PCR Detection of Hepatitis C Virus RNA from Human Serum}

Hepatitis C virus (HCV) is responsible for most cases of post-transfusion non- $A$, non-B hepatitis. ${ }^{(1)}$ PCR is a highly sensitive test for detection of HCV RNA in biological specimens and is a potentially powerful tool in laboratory diagnosis of HCV infection. Serum HCV RNA determination may eventually be required for prevention of blood-borne $\mathrm{HCV}$ transmission. ${ }^{(2)}$ To control contamination this would require automation of the PCR technology, a development that is presently hampered by technical difficulties. One of the main obstacles is the necessity of extracting viral RNA before amplification, a time-consuming step that is not readily automatable. Several alternative methods for sample processing for HCV reverse transcription (RT)PCR have been reported, ${ }^{(3,4)}$ all tending toward a much shorter and simpler procedure.

Here, we describe a simple method for RT-PCR amplification of HCV RNA from human serum that does not require any extra RNA extraction step. The method is based on the finding that Triton $\mathrm{X}-100$ can release HCV RNA from the viral envelope and that this can be efficiently reverse-transcribed from the crude lysate. The protocol is as follows: One to two microliters of serum diluted with 8-9 $\mu \mathrm{l}$ of fetal calf serum (HyClone) is added directly to the RT mix (50 mM $\mathrm{KCl}, 10 \mathrm{~mm}$ Tris- $\mathrm{HCl}$ at $\mathrm{pH} 9.0,4 \mathrm{~mm}$ $\mathrm{MgCl}_{2}, 0.1 \%$ Triton X-100, 20 units of RNasin ribonuclease inhibitor (Promega Corp., Madison, WI), $150 \mathrm{ng}$ of an HCVspecific antisense primer 20 (5'-GCT CAT GGT GCA CGG TCT A, position -13 to +6 of the viral genome), $200 \mu \mathrm{M}$ dNTPs, and 7.5 units of avian myeloblastosis virus (AMV)-RT (Promega) in a final volume of $20 \mu \mathrm{l}$. Fetal calf serum is used as a stabilizer to prevent coagulation during the denaturation step following cDNA synthesis. In view of the known homology between $\mathrm{HCV}$ and animal pestiviruses, ${ }^{(5)}$ and the possibility of contamination of fetal calf serum by bovine viral diarrhea virus (BVDV), ${ }^{(6)}$ care should be taken in both the design of PCR primers and in the use of virusscreened fetal calf serum. BVDVscreened fetal calf serum is widely available. New lots of fetal calf serum are evaluated for their ability to yield expected titer of our positive control HCVinfected serum and for negative results with a panel of noninfected control sera. cDNA synthesis is carried out at $43^{\circ} \mathrm{C}$ for
60 min followed by denaturation for 15 min at $90^{\circ} \mathrm{C}$; PCR mix is added $[50 \mathrm{~mm}$ $\mathrm{KCl}, 100 \mathrm{~mm}$ Tris- $\mathrm{HCl}$ at $\mathrm{pH} 9.0,2 \mathrm{~mm}$ $\mathrm{MgCl}_{2}, 0.1 \%$ Triton X-100, 2.5 units of Taq DNA polymerase (Promega), $200 \mu \mathrm{M}$ dNTPs, and $150 \mathrm{ng}$ each of sense and antisense primers $(21,22)$ ] to a final volume of $50 \mu \mathrm{l}$. One round of PCR is performed with the set of primers [21, 5'-CTG TGA GGA GCT ACT GTC T (nucleotides 4564 , numbered from the 5 ' end of the genome); 22, 5'-ACT CGC AAG CAC CCT ATC A (nucleotides 293-312)] located in the $5^{\prime}$ nonstructural region of the viral genome, generating a PCR product of $267 \mathrm{bp}$. PCR cycles are as follows: The first five cycles $\left(94^{\circ} \mathrm{C}\right.$ for $1.5 \mathrm{~min}, 72^{\circ} \mathrm{C}$ for $5 \mathrm{~min}$ ) were followed by 35 cycles of $94^{\circ} \mathrm{C}$ for $1.5 \mathrm{~min}, 60^{\circ} \mathrm{C}$ for $2 \mathrm{~min}$, and $72^{\circ} \mathrm{C}$ for $3 \mathrm{~min}$, followed by $72^{\circ} \mathrm{C}$ for 7 min. Amplified products were detected by oligomer hybridization ${ }^{(7)}$ with a ${ }^{32} \mathrm{P}$ end-labeled probe (positions 161-180; 5'-GAG TAC ACC GGA ATT GCC AG) located between the primers. The probetarget duplex was separated from unhybridized probe by NuSieve 3:1 agarose gel electrophoresis. The gel was then dried and autoradiographed. Alternatively, PCR, using a biotinylated antisense primer, was followed by detection of PCR product using an experimental enzyme-linked hybridization capture assay kindly provided by Roche Molecular Systems (Branchburg, NJ).

The present method detected $\mathrm{HCV}$ RNA using $1 \mu \mathrm{l}$ of $10^{-5}$ to $10^{-7}$ dilutions of our positive control serum that titered $10^{-5} / 50 \mu \mathrm{l}$ by nested PCR after a standard guanidinium/phenol/chloroform extraction and alcohol precipitation. ${ }^{(2)}$ This control serum was chosen as having the highest titer among 19 PCR-positive blood donors sera tested. ${ }^{(2)}$ Thus, the present method is $50-500$ times more sensitive than nested PCR. This was confirmed by analysis of five different plasma specimens that had been titrated by RT-PCR after guanidinium/phenol/ chloroform extraction. These sera had been chosen to have intermediate titer $\left(10^{-2}\right)$ in nested PCR titrations. As shown in Table 1, the direct method was 10 - to 100 -fold more sensitive for dilution of HCV RNA in $4 / 5$ sera even when the volume of sample tested is not taken into account. In one serum the two methods were of equivalent sensitivity.

The specificity of the method was demonstrated by our experience in 
testing serial specimens from infected chimpanzees. Preinoculation specimens from $>20$ animals were uniformly negative.

To determine whether the success of this method depended on the Triton $\mathrm{X}-100$ present in the cDNA reaction mix, we prepared cDNA solutions with and without detergent. Triton X-100 was removed from AMV-RT by mixing $40 \mu \mathrm{l}$ of AMV-RT with $5 \mathrm{mg}$ of $\mathrm{C} 18$ resin (Waters, Millipore Corp.) that had been washed with isopropanol and distilled water at room temperature for $3 \mathrm{~min}$, and repeating the process once. This method is known to remove $>99 \%$ of Triton X-100. ${ }^{(8)} \mathrm{C} 18$ resin-treated AMVRT was added to cDNA reaction mixtures with and without Triton X-100. After cDNA synthesis, the reaction mix was held at $100^{\circ} \mathrm{C}$ for $60 \mathrm{~min}$ to inactivate AMV-RT. As shown on Figure 1, detection of HCV RNA required the presence of Triton X-100 in the cDNA reaction buffer.

In conclusion, we have described a very simple RT-PCR protocol for the detection of HCV RNA that does not need an additional RNA extraction step. This modification would greatly facilitate large-scale HCV RNA detection, such as blood donor screening for HCV RNA. If combined with enzyme-linked hybridization capture assays for PCR product detection, the present method should contribute to a wider application of $\mathrm{HCV}$ RNA determination in clinical laboratories and blood banks.

TABLE 1 Semiquantitation of $\mathrm{HCV}$ RNA from Five Plasma Samples by Nested PCR after Guanidium/Phenol/ Cholorform Extraction and Alcohol Precipitation in Comparison to Direct Amplification

\begin{tabular}{lcc}
\hline Plasma & $\begin{array}{l}\text { Titer by } \\
\text { nested PCR } \\
\text { no. }\end{array}$ & $\begin{array}{r}\text { Titer by direct } \\
\text { amplification }\end{array}$ \\
\hline 220 & $10^{2}-\mu$ l sample $)$ & $(1-\mu l$ sample $)$ \\
231 & $10^{2}$ & $10^{3}$ \\
315 & $10^{2}$ & $10^{3}$ \\
341 & $10^{2}$ & $10^{3}$ \\
342 & $10^{2}$ & $>10^{4}$ \\
\hline
\end{tabular}

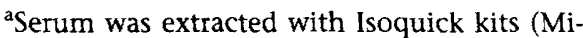
croProbe Corporation, Garden Grove, CA), and CDNA synthesis and nested PCR was carried out as described. ${ }^{(2)}$

bPCR product was detected by microplate hybridization capture assay.

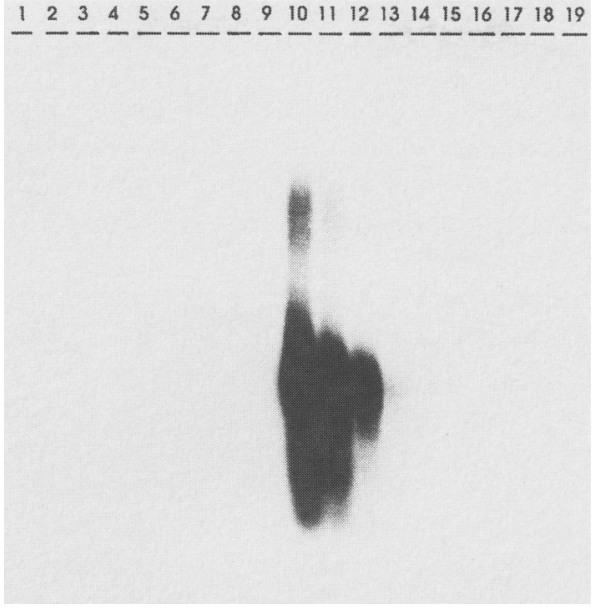

FIGURE 1 Requirement for Triton X-100 for release of HCV RNA. (Lanes 1-6,10-15) Tenfold serial dilutions of $10^{-1}-10^{-6}$ of an HCV RNA-positive plasma (no. 22; Table 1), starting with $10^{-1}$ dilutions in lanes 1 and 10 . Lanes 7-9 and 16-19 are negative controls. RT was performed without Triton X-100 (lanes $1-9)$ and with $0.1 \%$ Triton $X-100$ in the RT mix (lanes 10-19). PCR products were identified by oligomer hybridization in solution, electrophoresis, and autoradiography. Peak radioactivity of the gel corresponds to the expected product of $268 \mathrm{bp}$.

\section{ACKNOWLEDGMENTS}

This work was support in part by World Health Organization (WHO), grant MIM/V24/181/39. Superb technical support was provided by Donna Pascual and Maggie McCarthy. The manuscript was expertly prepared by Jacquelyn Anderson.

\section{REFERENCES}

1. Choo, Q.-L., A. Weiner, L.R. Overby, G. Kuo, and M. Houghton. 1990. Hepatitis C virus: The major causative agent of viral non-A, non-B hepatitis. Br. Med. Bull. 46: 423-430.

2. Sugitani, M., G. Inchauspé, M. Shindo, and A.M. Prince. 1992. Sensitivity of serological assays to identify blood donors with hepatitis $C$ viraemia. Lancet 339: 1018-1019.

3. Ravaggi, A., D. Primi, and E. Cariani. 1992. Direct PCR amplification of HCV RNA from human serum. PCR Methods Applic. 1: 291-292.

4. Kaneko, S., T. Mitani, T. Jhomoro, E. Suzuki, Y. Hayashi, M. Unoura, S. Murakami, and K. Kobayashi. 1992. Simple detection of hepatiis $C$ virus RNA: Application and significance in clinical diagnosis. Hepatology 16: 207A.
5. Han, J.H., V. Shyamala, K.H. Richman, M.J. Brauer, B. Irvine, M.S. Urdea, P. Tekamp-Olson, G. Kuo, Q.-L. Choo, and M. Houghton. 1991. Characterization of the terminal regions of hepatitis $C$ viral RNA: Identification of conserved sequences in the $5^{\prime}$ untranslated region and poly(A) tails at the $3^{\prime}$ end. Proc. Natl. Acad. Sci. 88: 1711-1715.

6. Nuttall, P.A., P.D. Luther, and E.J. Stott. 1977. Viral contamination of bovine fetal serum and cell cultures. Nature 266: 835837.

7. David E., D.E. Kellogg, and S. Kwok. 1990. Detection of human immunodeficiency virus. In PCR protocols: A guide to methods and applications (ed. M.A. Innis, D.H. Gelfand, J.J. Sninsky, and T.J. White), pp. 337-347. Academic Press, New York.

8. Horowitz, B., R. Bonomo, A.M. Prince, S.N. Chin, B. Brotman, and R.W. Shulman. 1992. Solvent/detergent-treated plasma: A virus-inactivated substitute for fresh frozen plasma. Blood 79: 826-831.

Received October 20, 1993; accepted in revised form February 16, 1994. 


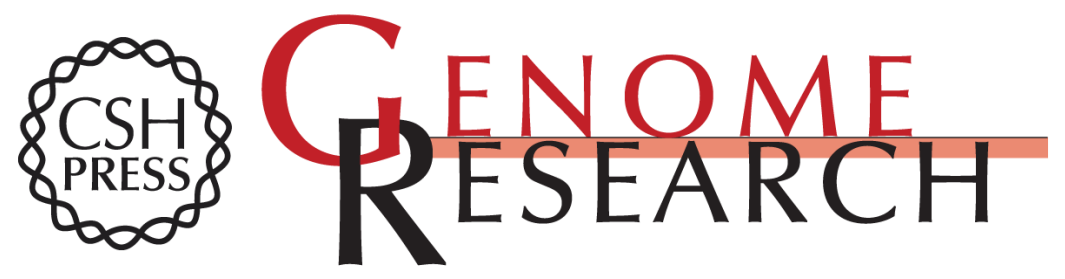

\section{A simplified method for PCR detection of hepatitis C virus RNA from human serum.}

J Lai, A M Prince, L Wolfe, et al.

Genome Res. 1994 3: 308-309

References This article cites 7 articles, 2 of which can be accessed free at: http://genome.cshlp.org/content/3/5/308.full.html\#ref-list-1

License

Email Alerting

Receive free email alerts when new articles cite this article - sign up in the box at the Service top right corner of the article or click here.

\section{Affordable, Accurate Sequencing.}

To subscribe to Genome Research go to: https://genome.cshlp.org/subscriptions 